\title{
Application of a Series of Continuously Fed Aerated Tank Reactors System for Recycling of Swine Slurry Nutrients
}

\author{
Anni Alitalo ${ }^{1}$, Tuomas Pelto-Huikko² \& Erkki Aura ${ }^{3}$ \\ ${ }^{1}$ MTT Agrifood Research Finland, Plant Production Research, Soil and Plant Nutrition, Koetilantie, Helsinki, \\ Finland \\ ${ }^{2}$ Faculty of Science and Environmental Engineering, Tampere University of Technology, Tampere, Finland \\ ${ }^{3}$ Biotaito, Killintie, Tammela, Finland \\ Correspondence: Anni Alitalo, MTT Agrifood Research Finland, Plant Production Research, Soil and Plant \\ Nutrition, Koetilantie 5, 00790 Helsinki, Finland.
}

Received: December 7, 2012 Accepted: December 31, 2012 Online Published: January 11, 2013

doi:10.5539/jsd.v6n2p26

URL: http://dx.doi.org/10.5539/jsd.v6n2p26

\begin{abstract}
Single tank aeration systems operated in batch mode or sequential batch reactors based on intermittent aeration are generally applied for swine manure treatment in order to reduce nutrient content and odor. This study evaluated the feasibility of aerobic biological treatment conducted in a serial arrangement of continuously fed aerated tank reactors configuration with swine slurry on a pilot-scale. Compared to municipal wastewater treatment swine slurry rich in nutrients and solids requires different treatment standards for the applied methods to be economically and ecologically relevant. This study presents a sequential process scheme, in which biological treatment serves as a means of achieving a $\mathrm{pH}$ raise. This makes it possible to separate part of the nitrogen by stripping and enhances slurry precipitating/coagulation characteristics without substantial carbon or nitrogen loss in gaseous form (which is the opposite to that in a conventional active sludge process). The system was run with a hydraulic retention time (HRT) of three to four days (whole system), and a feedback of $0.8 \pm 0.2$. During treatment, total organic carbon (TOC) reduction varied between $2.4 \%$ and $14.6 \%$ and the total nitrogen concentration change was less than $3 \%$. Nearly $50 \%$ of the total phosphorus was reduced. The results indicated that the odor of liquid manure had decreased efficiently at best to a level at which there was no odor or only very faint odor. Concurrently, manure $\mathrm{pH}$ rose to 8.7.
\end{abstract}

Keywords: swine manure, aerobic treatment, serial, feedback, odor, total treatment

\section{Introduction}

For environmental and economic reasons, recycling the nutrients of livestock manure has become increasingly important for reducing the use of mineral fertilizers for crop production, particularly in the intensive animal production areas. Considerable efforts are currently underway to develop practical and affordable ways to reduce manure odor and recycle manure nutrients.

Aerobic processes have been common in the treatment of contaminated effluents due to their ability to convert contaminants into less harmful substances. The activated sludge process represents the most widespread technology for wastewater treatment. The process is not directly usable for manure treatment due to the relatively concentrated state of manure compared to waste water; that is, it has relatively high dry matter and nutrient contents and buffer capacity. However, aeration of animal slurry as a method of removing the offensive odor has attracted a certain amount of interest. Biodegradation of organic compounds related to odor generation (Westerman \& Zhang, 1997; Zhu, 2000) decreases the odor intensity. Complete aerobic treatment (analogous to sewage treatment) demands high energy input and may be economically unprofitable.

Commercial odor control agents have also been applied. However, the effectiveness of additives, particularly commercially available products, has been a subject of debate (Pain et al., 1987; Ritter, 1981; Zhu et al., 1997). Masking, disinfecting and oxidizing agents can provide short-term control of malodor, but because the capacity of these additives is finite, they require frequent reapplication. Microbial-based digestive additives may offer a solution to this problem as they are regenerative; however, such additives appear to have been developed without a thorough understanding of the microbiological processes that occur in livestock wastes. Grubbs (1979) claimed 
that the key to successful bacterial additives is that the added culture must become the dominant strain within the microbial community. At the very least, the added microorganisms must be able to grow, reproduce and become a part of the indigenous community. This would require them to be successful within the required environmental parameters, including temperature, $\mathrm{pH}$, dissolved oxygen concentration, nutrient availability and the ability to withstand potential toxins.

Complete aeration, with the goal of reducing the biological oxygen demand (BOD), suspended solids and nutrients to achieve requirement levels for discharge to surface waters, is not an ecological option for liquid manure. Therefore, the manure treatment approach should be different from that of waste water and the ultimate goal should be complete nutrient recycling. This could be achieved through the following steps: (1) partial separation of phosphorus (in plant available form) and solid material prior to aerobic biological treatment; (2) conversion of manure through biological treatment into a form that enables further fractionation of manure effluent, (3) $\mathrm{N}$ separation with air stripping after the reduction of manure solid matter and biological $\mathrm{pH}$ raise (Alitalo et al., 2012) and (4) only after phosphorus and nitrogen removal and subsequent buffer capacity reduction; chemical treatment with reduced amounts of chemical coagulants, such as iron salts, aluminium salts or polymers.

This paper presents the results of the study concerning aerobic biological treatment. The general aim of the study was to test how moderate or only slight aeration influences manure slurry properties when conducted in the specially designed reactor system. More specifically, the study investigated whether it is possible to efficiently raise slurry $\mathrm{pH}$ without turning ammonium to nitrate with aeration treatment or losing it in gaseous form or losing a substantial fraction of the carbon. The study also investigated whether the slurry-precipitating characteristics can be strengthened and how the system influences odor.

\section{Materials}

This study was conducted on a sow farm located in southwestern Finland. The characteristics of untreated raw manure are presented in Table 1.

Table 1. Characteristics of the untreated swine manure used in this study. Total solids (TS) content (\%), total carbon (TC), total organic carbon (TOC), total nitrogen (Ntot), ammonium nitrogen $\left(\mathrm{NH}_{4}{ }^{+}-\mathrm{N}\right)$, total phosphorus (Ptot), phosphate phosphorus $\left(\mathrm{PO}_{4}{ }^{3-}-\mathrm{P}\right)$, calcium $\left(\mathrm{Ca}^{2+}\right)$, magnesium $\left(\mathrm{Mg}^{2+}\right)$, potassium $\left(\mathrm{K}^{+}\right)$and sodium $\left(\mathrm{Na}^{+}\right)$ concentration in $\mathrm{mg} / \mathrm{L}$. The mean value of five replicates and standard deviation are shown

\begin{tabular}{cccccccccccc}
\hline & $\mathrm{TS}$ & $\mathrm{TC}$ & $\mathrm{TOC}$ & $\mathrm{Ntot}$ & $\mathrm{NH}_{4}^{+} \mathrm{N}$ & $\mathrm{Ptot}$ & $\mathrm{PO}_{4}^{3-}-\mathrm{P}$ & $\mathrm{Ca}^{2+}$ & $\mathrm{Mg}^{2+}$ & $\mathrm{K}^{+}$ & $\mathrm{Na}^{+}$ \\
\hline mean & 1.85 & 4962 & 3930 & 2255 & 1649 & 451 & 180 & 635 & 203 & 1188 & 668 \\
s.d. & 0.10 & 425 & 41 & 111 & 62 & 102 & 89 & 146 & 64 & 89 & 155 \\
\hline
\end{tabular}

\section{Method}

\subsection{Installation of Treatment System}

Six continuously fed aerated reactor tanks in a chain, connected by polyvinyl tubing ( $65 \mathrm{~mm}$ in inner-diameter), were operated in series (Figure 1). The volume of the polyethylene tank was $600 \mathrm{~L}$ and the hydraulic volume of the total system was $2.96 \mathrm{~m}^{3}$. The feed-in flow in each tank was to the bottom of the tank and outflow through the crosswise upper corner in relation to the input flow. The surface liquid/effluent level remained constant when liquid manure ran gravitationally from one tank to another. Perforated tubes $(1.9 \mathrm{~m}$ in length, $16 \mathrm{~mm}$ in inner diameter) were installed at the bottom of each tank and were used for aeration and mixing. Air pressure was produced by compressor (OMA CT4-B3800-150) and was divided to each tank by a 'delivery log'. A pressure meter controlled the feed-in air pressure to each tank, which was adjusted by a pressure regulator. Recirculation (feedback) of effluent slurry from the last tank to the first tank was also introduced. 


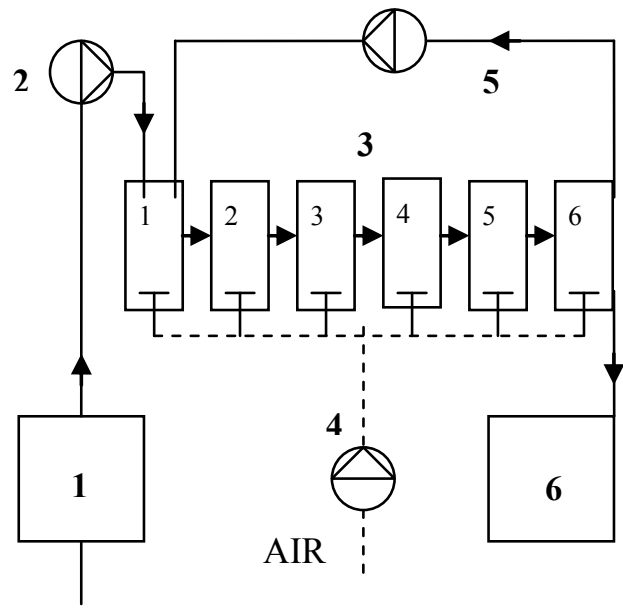

Manure

Figure 1. Flow chart of the biological treatment process

In order to set up the system, the tanks were filled in with produced effluent (subcultured inoculant). This inoculant was produced in a similar configuration to that described above. Six 30-L plastic tanks were filled with diluted soil-water $(1 \% \mathrm{v} / \mathrm{v})$ suspension. The suspension was aerated at room temperature $\left(19-22^{\circ} \mathrm{C}\right)$, while small amounts (less than 1:50 v/v) of liquid manure were added daily to the first tank. The volume of added manure was gradually increased. However, the additions were scaled to maintain the last tank odorless. The feedback rate from the last tank to the first was $1: 1 \mathrm{v} / \mathrm{v}$. This system was operated for over a year prior to filling the $600-\mathrm{L}$ treatment tanks with the produced effluent.

After filling the treatment system with effluent, manure treatment began. Manure was pumped from a reception pit of a sow house into a $1 \mathrm{~m}^{3}$ plastic subcontainer (Figure 1) in which the solid fraction was separated by sedimentation. The separated liquid manure was fed continuously from the subcontainer into the first tank of the system.

\subsection{Experimental Procedure to Examine the Process Operating Parameters}

Over a period of two months prior to the actual start of the experimental runs, liquid manure was fed into the process so that the hydraulic retention time (HRT) of a whole system varied between five and ten days and the feedback (recirculation ratio) was approximately 1 . Experimental runs were started by adjusting the HRT to four days (whole system) and taking samples after one week $(\mathrm{HRT}=4 \mathrm{~d})$. Thereafter, the HRT was adjusted to three days (whole system) and the process was run for a three-week period, taking samples after every week (HRT = $3 d$ ). Feedback was kept at $0.8 \pm 0.2$ (recirculation ratio).

In order to evaluate the process conditions, the dissolved oxygen (DO) content and the temperature in each tank were measured with an YSI meter (95/100 FT; YSI Inc., Yellow Springs, USA) and pH with a pH probe (9107BN, Orion, USA). Measurements were carried out daily at a depth of approximately $10 \mathrm{~cm}$.

\subsection{Sampling and Analyses}

Liquid manure samples from the subcontainer and six tanks were stored at $-20^{\circ} \mathrm{C}$ immediately after collection. Finnish Standard Associations methods were used for total solids (TS) and volatile solids (VS) analysis (SFS 3008). The chemical oxygen demand (COD) was analyzed according to standard SFS 5504 with HACH's closed tubes (dichromate oxidation). The volatile fatty acids (VFAs), total organic carbon (TOC), total phosphorus (Ptot), total nitrogen (Ntot), $\mathrm{PO}_{4}{ }^{3-}-\mathrm{P}, \mathrm{NH}_{4}{ }^{+}-\mathrm{N}, \mathrm{NO}_{3}{ }^{-}-\mathrm{N}, \mathrm{K}^{+}, \mathrm{Mg}^{2+}, \mathrm{Ca}^{2+}$ and $\mathrm{Na}^{+}$analyses were made as described by Alitalo et al (2012). Analyses were carried out on the total sample for TS, VS, COD, TOC, Ptot and Ntot and on the centrifuged supernatant for VFA, anions and cations.

The feedback of slurry from the last tank results in a dilution effect. This was accounted for by incorporating the effect of the feedback solution into the calculations as follows:

$$
\left[\left(\mathrm{C}_{\text {in }}{ }^{*} \mathrm{Q}_{\text {in }}\right)+\left(\mathrm{C}_{\text {back }} * \mathrm{Q}_{\text {back }}\right)\right] /\left[\mathrm{Q}_{\text {in }}+\mathrm{Q}_{\text {back }}\right]
$$


where $\mathrm{C}_{\mathrm{in}}$ is the feed-in concentration, $\mathrm{Q}_{\mathrm{w}}$ is the feed-in volume, $\mathrm{C}_{\mathrm{back}}$ is the feedback concentration, and $\mathrm{Q}_{\text {back }}$ is the feedback volume. The difference between the analyzed and the calculated concentration in the $1^{\text {st }}$ tank is the reduction due to coagulation or precipitation. Changes during processing are calculated as concentration changes between the $1^{\text {st }}$ and the $6^{\text {th }}$ treatment tank.

\subsection{Evaluation of Odor}

Manure samples for odor intensity determinations were taken from the subcontainer and the tanks of treatment system at the same time as the samples for chemical analyses. The odor intensity using a ranking method was determined in a laboratory using a panel score (consisting of five to eight panelists) within two hours of sampling (Powers, 2004). The panelists were required to indicate the subjective strength of the odor of samples according to the following scale derived by Paduch (1988), 0 no odor; 1 very faint odor; 2 faint odor; 3 distinct odor; 4 strong odor; 5 very strong odor; and 6 extremely strong odor.

\subsection{UV/Visible}

For the UV/Vis measurements, an Agilent 5438 spectrophotometer was used. The absorption spectra were measured from 200 to $900 \mathrm{~nm}$. Microbe filtrated samples (through $0.45 \mu \mathrm{m}$ pore size bacteriological filters, Whatman) were measured in $3 \mathrm{ml}$ quartz cuvettes with a $1.0 \mathrm{~cm}$ optical path.

\subsection{Statistical Analyzes}

The statistical differences between the different HRT values in TS, VS, TOC, COD, VFA, odor and nutrient contents were determined using the MIXED procedure of SAS (Littell et al., 1996). The data was analyzed as a randomized block design (the subcontainer and six reactor tanks as block factors). The data during processing (six reactor tanks) was also analyzed with linear regression analyzes of SAS to evaluate the influence of tank on odor, TS, VS, TOC, COD, VFA and nutrient contents, respectively.

\section{Results}

\subsection{Temperature, $\mathrm{DO}$ and $\mathrm{pH}$}

During the experimental runs, the temperatures in the tanks varied between 15.6 and $21.1^{\circ} \mathrm{C}$ and the $\mathrm{DO}$ content from 0.6 to $7.2 \mathrm{mg} / \mathrm{L}$. As Table 2 shows, when HRT $=3 \mathrm{~d}$ the DO content in the aeration basins was slightly lower and its variation was wider than with parameters of $\mathrm{HRT}=4 \mathrm{~d}$.

Table 2. DO-content (min-max, mg/L) in tanks (1 to 6) of treatment system with different hydraulic retention time (HRT), four and three days, respectively

\begin{tabular}{ccccccc}
\hline$H R T(d)$ & Tank 1 & Tank 2 & Tank 3 & Tank 4 & Tank 5 & Tank 6 \\
\hline 4 & $1.5-5.5$ & $4.4-5.9$ & $4.1-6.9$ & $3.8-7.1$ & $3.4-5.5$ & $4.7-7.2$ \\
3 & $0.7-5.5$ & $0.6-5.4$ & $1.0-5.8$ & $1.1-6.5$ & $0.8-4.9$ & $0.9-6.0$ \\
\hline
\end{tabular}

The $\mathrm{pH}$ in the first tank was approximately $0.8 \mathrm{pH}$-units higher than that of the untreated manure and, at the end of the process (tank 6), generally rose above $\mathrm{pH} 8.5$ (Table 3 ).

Table3. pH-values (min-max) in subcontainer (untreated manure, tank 0$)$ and tanks ( 1 to 6 , biologically treated manure) of treatment system with different hydraulic retention time (HRT), three and four days, respectively

\begin{tabular}{cccccccc}
\hline HRT $(d)$ & Tank 0 & Tank 1 & Tank 2 & Tank 3 & Tank 4 & Tank 5 & Tank 6 \\
\hline 4 & $7.1-7.4$ & $8.0-8.3$ & $8.2-8.4$ & $8.3-8.5$ & $8.3-8.6$ & $8.3-8.6$ & $8.3-8.6$ \\
3 & $7.2-7.4$ & $8.2-8.3$ & $8.2-8.4$ & $8.3-8.6$ & $8.4-8.6$ & $8.4-8.7$ & $8.4-8.6$ \\
\hline
\end{tabular}

\subsection{TS, VS, TOC and COD}

There was a slight decrease in the TS levels of liquid manure during the course of treatment (Figure 2A). Some sedimentation to the bottom of the treatment tanks might have occurred despite continuous aeration. Part of the loss could be attributed to the breakdown of organic matter by the metabolic action of micro-organisms. Determined TS reduction in the first tank ranged from $5.9 \%$ (with HRT $=3$ ) to $7.5 \%$ (with HRT $=4$ ) when feedback dilution reduced TS content from $4.3 \%$ (with HRT $=3$ ) to $5.9 \%$ (with HRT $=4$ ). Thus, the amount that 
was precipitated or coagulated in the first tank was $1.6 \%$ (difference between the analyzed and the calculated concentrations) irrespective of treatment run. TS reduction, during processing (from tank 1 to tank 6), ranged from $3.8 \%$ to $6.1 \%$. The highest TS reduction $(6.1 \%)$ was achieved with HRT $=4$, $\left(\mathrm{R}^{2}=0.864 ; \mathrm{p}<0.01\right.$, Table 4$)$. Total TS reduction (untreated slurry $-6^{\text {th }}$ tank) was $9.5-13.2 \%$ after treatment.

Essentially, the characteristics of VS changes were similar to those of TS (Figure 2B). During processing, the reduction was $5.3 \%$ with $\mathrm{HRT}=3$ and $7.5 \%$ with $\mathrm{HRT}=4$. The difference in change in VS between the different HRT values was significant $(p<0.001$, Table 4). However, this difference was likely due to initial VS concentration difference between the two experiments.

The TOC concentration reduction of liquid manure varied between $2.4 \%$ (with HRT $=3$ ) and $14.6 \%$ (with HRT $=4$ ) during the course (from tank 1 to tank 6) of treatment (Figure 2C). The amount of dissolved inorganic carbon (DIC) was reduced from $1520 \mathrm{mg} / \mathrm{L}$ (with $\mathrm{HRT}=3$ ) and $1606 \mathrm{mg} / \mathrm{L}$ (with $\mathrm{HRT}=4$ ) before treatment to $1351 \mathrm{mg} / \mathrm{L}$ (with HRT=3) and $1288 \mathrm{mg} / \mathrm{L}$ (with $\mathrm{HRT}=4$ ). Thus, $\mathrm{CO}_{2}$ was released from the system during treatment. The effect of aerobic biological treatment on COD varied between experimental runs (Figure 2D). During processing the COD reduction of $39.3 \%$ was achieved with HRT $=4 \mathrm{~d}$, whereas the reduction with HRT $=3 \mathrm{~d}$ was only $11.8 \%$.

A

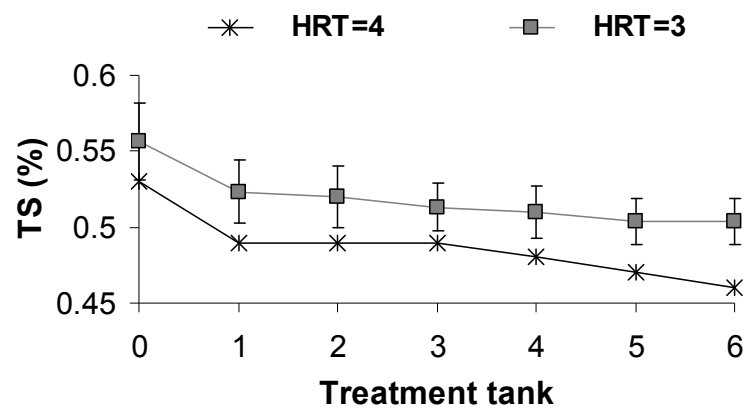

$\mathrm{C}$

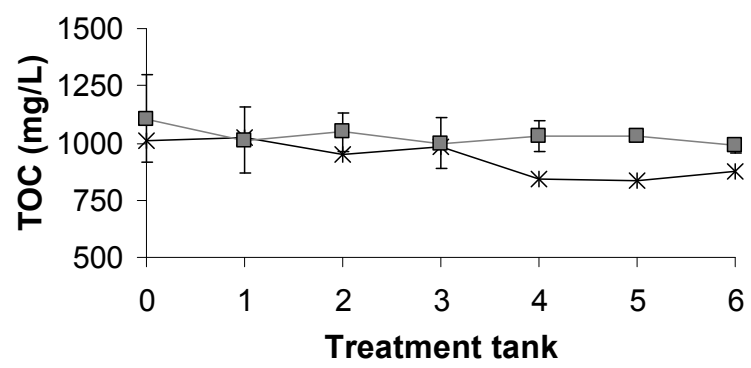

B

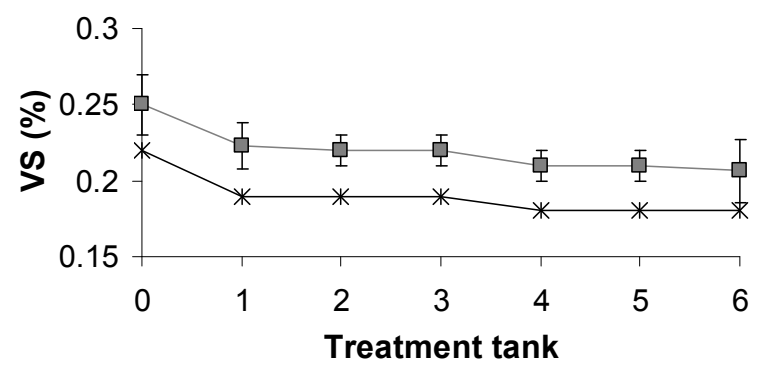

$\mathrm{D}$



Figure 2. Total solids (A), volatile solids (B), total organic carbon (C) and chemical oxygen demand in subcontainer ( 0 untreated manure) and tanks ( 1 to 6 , biologically treated manure) of treatment system with

hydraulic retention time of three and four days, respectively. Error bars indicate standard deviation

\subsection{Characteristics of $\mathrm{N}, \mathrm{P}, \mathrm{Ca}^{2+}, \mathrm{Mg}^{2+}, \mathrm{K}^{+}$and $\mathrm{Na}^{+}$}

The Ntot concentration of untreated liquid manure varied between $1482-1535 \mathrm{mg} / \mathrm{L}$ and Ptot concentration ranged from 78-87 mg/L (Figure 3A and B). The low concentration of phosphorus was probably caused by the sedimentation/separation of slurry solid matter in the subcontainer (Figure 1). The Ntot concentration only decreased significantly when HRT $=4\left(\mathrm{R}^{2}=0.901 ; \mathrm{p}<0.01\right.$, Table 4$)$. In other words, the Ntot concentration changes during processing were less than $3 \%$ regardless of the treatment run. No significant change in $\mathrm{NH}_{4}{ }^{+}-\mathrm{N}$ concentration was determined during the experimental runs (Figure 3A). However, the majority of the nitrogen 
was in ammonia form 1309-1344 $\mathrm{mg} / \mathrm{L}$. The amount of nitrate was small, with its concentration varying between 9.9 and $31.2 \mathrm{mg} / \mathrm{L}$.

The greatest Ptot concentration changes occurred in the first tank, when the analyzed reduction was $21-30 \%$. The Ptot reduction due to coagulation or precipitation in the first tank varied from $6.2 \%$ to $8.0 \%$. Ptot reduction, during processing, ranged from $16 \%$ with $H R T=3\left(R^{2}=0.684 ; p<0.001\right.$, Table 4$)$ to $28 \%$ with HRT $=4$. In the final treatment tank, $31-49 \%$ of the original untreated manure containing Ptot was removed and the greatest reduction was obtained with treatment parameters $\mathrm{HRT}=4$ (which was significantly different from $\mathrm{HRT}=3$ ). Phosphate phosphorus concentration changes were only minor, irrespective of the treatment run (Figure 3B).

A

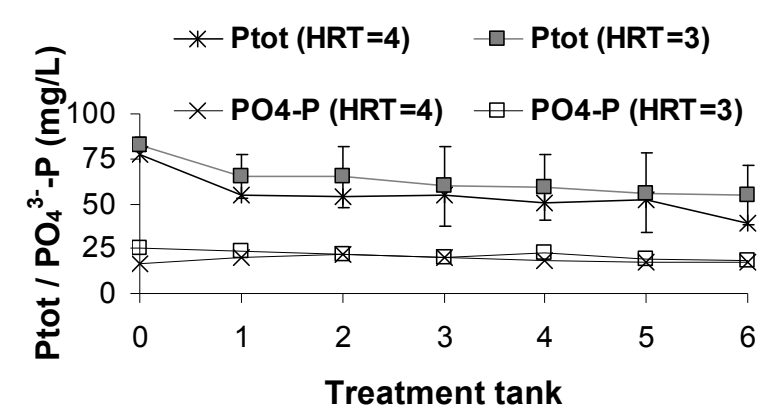

$\mathrm{C}$



$\mathrm{E}$

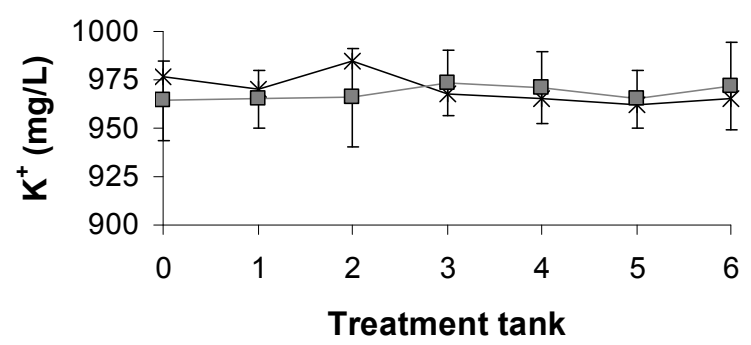

B

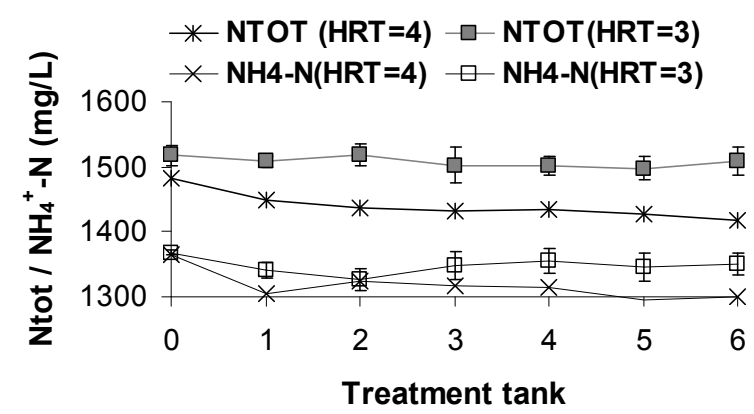

$\mathrm{D}$



$\mathrm{F}$

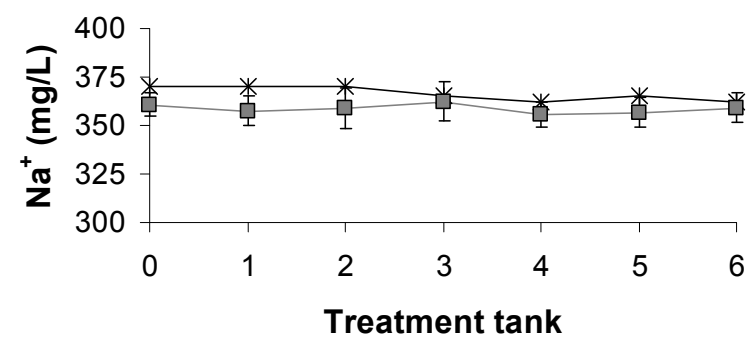

Figure 3. Total nitrogen or $\mathrm{NH}_{4}{ }^{+}-\mathrm{N}(\mathrm{A})$, Total phosphorus or orthophosphate phosphorus (B), $\mathrm{Ca}^{2+}(\mathrm{C}), \mathrm{Mg}^{2+}(\mathrm{D})$, $\mathrm{K}^{+}(\mathrm{E})$ and $\mathrm{Na}^{+}(\mathrm{F})$ ion concentrations $(\mathrm{mg} / \mathrm{L})$ in subcontainer $(0$ untreated manure) and tanks $(1$ to 6 , biologically treated manure) of treatment system with hydraulic retention time of three and four days, respectively. Error bars indicate standard deviation

Magnesium and calcium ion concentration changes were similar to those of total phosphorus (Figure 3C, D). In the first treatment tank, the determined $\mathrm{Mg}^{2+}$ and $\mathrm{Ca}^{2+}$ concentration declines were $30-39 \%$ and $0-12 \%$, respectively. The amount that was precipitated or coagulated in the first tank ranged from 10 to $11 \% \mathrm{with} \mathrm{Mg}^{2+}$, 
respectively, from 0 to $3 \%$ with $\mathrm{Ca}^{2+}$. The process time reduction in $\mathrm{Mg}^{2+}$ concentration ranged from $23 \%$ with HRT $=3\left(\mathrm{R}^{2}=0.745 ; \mathrm{p}<0.001\right.$, Table 4$)$ to $39 \%$ with HRT $=4\left(\mathrm{R}^{2}=0.963 ; \mathrm{p}<0.01\right.$, Table 4$)$ and $\mathrm{Ca}^{2+}$ concentration from $6 \%$ with HRT $=3$ to $7 \%$ with HRT $=4\left(\mathrm{R}^{2}=0.862 ; \mathrm{p}<0.01\right.$, Table 4$)$, respectively, depending on the treatment run. The greatest $\mathrm{Ca}^{2+}$ ion concentration change was observed with treatment parameters $\mathrm{HRT}=4$, when $36 \%$ of the $\mathrm{Ca}^{2+}$ had been removed; with $\mathrm{HRT}=3$, only a 5-12\% decline of the original $\mathrm{Ca}^{2+}$ concentration took place.

Virtually no change was observed in the concentrations of monovalent cations (potassium and sodium) during the treatment process (Figure 3E, F).

Table 4. Statistical differences between the different HRT values in TS, VS, TOC, COD, VFA, odor, and nutrient contents determined with the MIXED procedure of SAS. Level averages (between HRT $=3$ and HRT $=$ 4), which have no common letters $(a, b)$ differ from the paired comparison, significant at the $5 \%$ risk level. Statistically significant difference $(\mathrm{HRT}=3, \mathrm{HRT}=4) *, * *$ and $* * *$ at the probability level of $0.05,0.01$ and 0.001 , respectively. Linear regression analyses (intercept, factor, R2 and p-values shown)

\begin{tabular}{|c|c|c|c|c|c|c|}
\hline \multicolumn{3}{|c|}{ Analyses of variance } & \multicolumn{4}{|c|}{ Linear regression } \\
\hline & HRT (days) & Level average & Intercept & Factor & $\overline{\mathrm{R}^{2}}$ & p-value \\
\hline \multirow[t]{2}{*}{ TS } & $3^{\mathrm{a}^{* * *}}$ & 5.4 & 5.28 & -0.04 & 0.214 & $<0.053$ \\
\hline & $4^{b^{* * *}}$ & 4.9 & 5.02 & -0.06 & 0.864 & $<0.007$ \\
\hline \multirow[t]{2}{*}{ VS } & $3^{\mathrm{a}^{* * *}}$ & 2.3 & 2.27 & -0.04 & 0.229 & $<0.045$ \\
\hline & $4^{b^{* * *}}$ & 1.9 & 1.94 & -0.03 & 0.771 & $<0.021$ \\
\hline \multirow[t]{2}{*}{ TOC } & $3^{\mathrm{a}^{* * *}}$ & 1118 & 1032 & -4 & 0.083 & $<0.719$ \\
\hline & $4^{\mathrm{b}^{* * *}}$ & 951 & 1042 & -35.5 & 0.716 & $<0.036$ \\
\hline \multirow[t]{2}{*}{ COD } & $3^{\mathrm{a}^{* *}}$ & 2800 & 2647 & -51.4 & 0.056 & $<0.347$ \\
\hline & $4^{\mathrm{b}^{* *}}$ & 1917 & 2553 & -191 & 0.589 & $<0.075$ \\
\hline \multirow[t]{2}{*}{ VFA } & $3^{\mathrm{a}^{* * *}}$ & 433 & 480.9 & -8.6 & 0.821 & $<0.013$ \\
\hline & $4^{b^{* * *}}$ & 359 & 436.9 & -2.9 & 0.046 & $<0.392$ \\
\hline \multirow[t]{2}{*}{ Odor } & 3 & 2.5 & 2.82 & -0.1 & 0.135 & $<0.133$ \\
\hline & 4 & 2.2 & 3.41 & -0.5 & 0.939 & $<0.001$ \\
\hline \multirow[t]{2}{*}{ Ntot } & $3^{\mathrm{a}^{* * *}}$ & 1519 & 1512 & -1.5 & 0.024 & $<0.536$ \\
\hline & $4^{b^{* * *}}$ & 1433 & 1453 & -5.6 & 0.901 & $<0.004$ \\
\hline \multirow[t]{2}{*}{$\mathrm{NH}_{4}{ }^{+}-\mathrm{N}$} & $3^{\mathrm{a}^{* *}}$ & 1359 & 1331 & 2.5 & 0.031 & $<0.483$ \\
\hline & $4^{b^{* *}}$ & 1311 & 1319 & -2.8 & 0.25 & $<0.313$ \\
\hline \multirow[t]{2}{*}{ Ptot } & $3^{\mathrm{a}^{* * *}}$ & 62.9 & 68.1 & -2.3 & 0.684 & $<.0001$ \\
\hline & $4^{b^{* * *}}$ & 53.7 & 59.4 & -2.5 & 0.613 & $<0.066$ \\
\hline \multirow[t]{2}{*}{$\mathrm{PO}_{4}^{3-}-\mathrm{P}$} & $3^{\mathrm{a}^{*}}$ & 21.5 & 23.6 & -0.8 & 0.567 & $<0.084$ \\
\hline & $4^{\mathrm{b}^{*}}$ & 19.8 & 22.1 & -0.8 & 0.81 & $<0.015$ \\
\hline \multirow[t]{2}{*}{$\mathrm{Ca}^{2+}$} & $3^{\mathrm{a}^{* * *}}$ & 123 & 152 & -2.5 & 0.053 & $<0.356$ \\
\hline & $4^{\mathrm{b}^{* * *}}$ & 149 & 152.6 & -2.3 & 0.862 & $<0.008$ \\
\hline \multirow[t]{2}{*}{$\mathrm{Mg}^{2+}$} & $3^{\mathrm{a}^{* *}}$ & 31.1 & 35.3 & -1.7 & 0.745 & $<.0001$ \\
\hline & $4^{\mathrm{b}^{* *}}$ & 27.1 & 33.7 & -2.5 & 0.963 & $<0.005$ \\
\hline \multirow[t]{2}{*}{$\mathrm{K}^{+}$} & $3^{\mathrm{a}^{* *}}$ & 9878 & 966 & 0.8 & 0.007 & $<0.735$ \\
\hline & $4^{\mathrm{b}^{* *}}$ & 969 & 979 & -2.7 & 0.387 & $<0.187$ \\
\hline \multirow[t]{2}{*}{$\mathrm{Na}^{+}$} & 3 & 365 & 359 & -0.2 & 0.002 & $<0.876$ \\
\hline & 4 & 366 & 371 & -1.6 & 0.741 & $<0.028$ \\
\hline
\end{tabular}




\subsection{Odor}

Biological treatment of manure significantly reduced the odor intensity compared to that of untreated manure (Figure 4A). The untreated liquid manure was evaluated as having a very strong odor. The best odor reduction results were obtained with HRT $=4$; in the sixth tank, no odor or only a very faint odor was evaluated $\left(\mathrm{R}^{2}=\right.$ 0.939; $\mathrm{p}<0.01$, Table 4). Odor reduction was sensed in the first treatment tank, but a clearer decline (faint odor) was observed in the second tank. Thereafter, odor reduction ceased at about at this level with HRT $=3$, but continued with HRT $=4$.

A

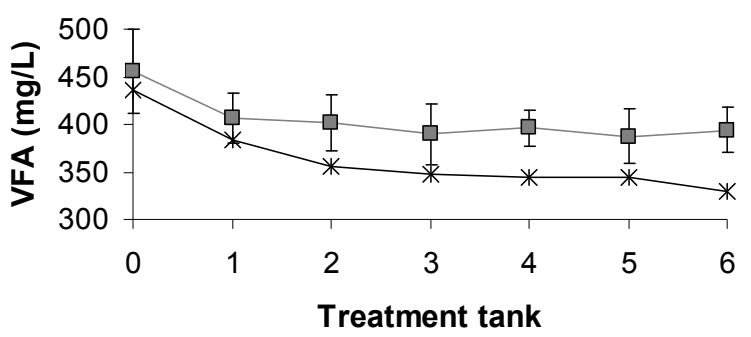

C

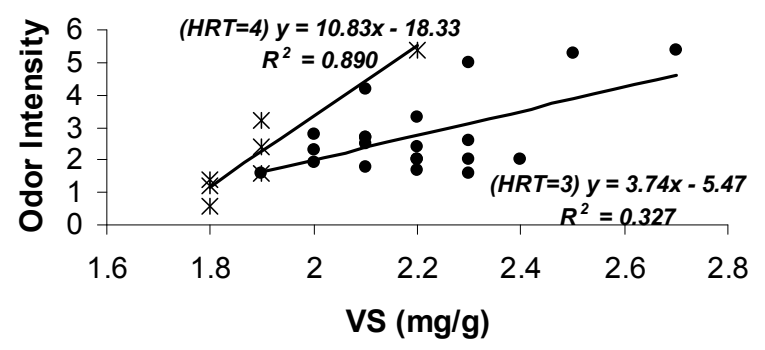

$\mathrm{E}$



B

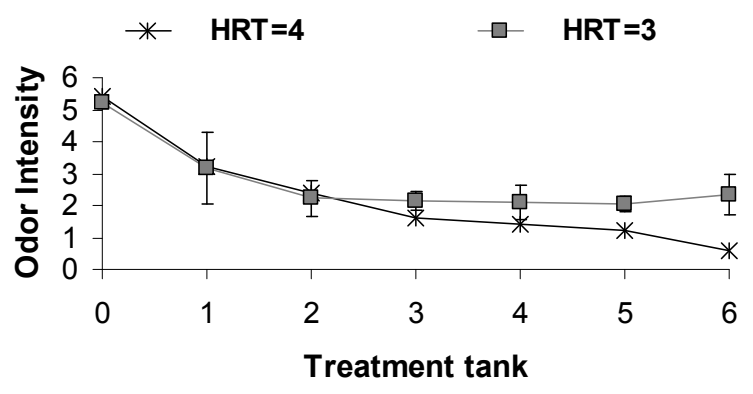

$\mathrm{D}$

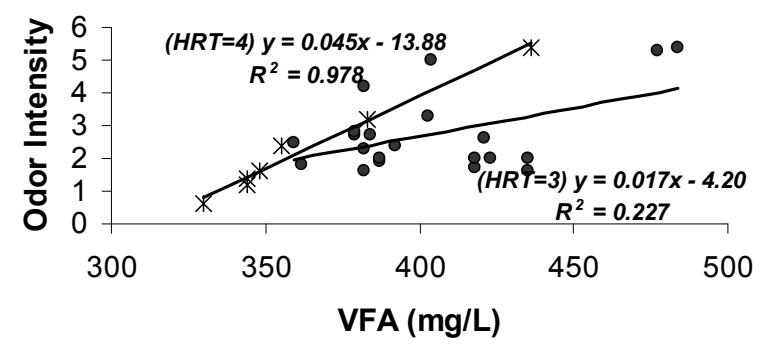

$\mathrm{F}$



Figure 4. Odor intensity (A), VFAs (mg/L) (B), linear regression equations for odor intensity versus VFA (C) and VS (D) in treatment tanks during treatment runs. Respectively, VFA versus TS (E) and VS (F) in treatment tanks during treatment runs. Error bars indicate standard deviation

The VFAs concentration was a less sensitive measure of the odor than the evaluated odor intensity. Generally, the total VFAs level of below $230 \mathrm{mg} / \mathrm{L}$ corresponds to manure without an offensive odor (Burton, 1992). The VFA concentrations in the present study, however, were much higher and varied from $330 \mathrm{mg} / \mathrm{L}$ to $484 \mathrm{mg} / \mathrm{L}$, although odor intensity was reduced to a level of no odor or only a very faint odor (Figure 4B, C). The VFA concentration of untreated liquid manure varied between $404-484 \mathrm{mg} / \mathrm{L}$. The highest VFA reduction during 
processing $(13 \%)$ was achieved with $\mathrm{HRT}=4$, whereas the reduction with $\mathrm{HRT}=3$ was $3 \%$. Linear regression equations for odor intensity versus VFA and VS showed strongly significant correlation with HRT $=4$, but a low correlation with HRT=3 (Figure 4C, D). A high correlation was found for VFA versus TS and VS, irrespective of treatment runs (Figure 4E, F).

\subsection{Physico-Chemical Changes Due to the Treatment}

Slurry color changed from grayish green to dark brown. The visually observed darkness intensified from one tank to the next. More clearly, the color change was observed in microbe filtered slurry samples (Figure 5). The absorbance spectra of samples taken from the last tanks samples showed higher absorbance than the untreated and first tank samples (Figure 6). The samples showed the maximum absorption at $\lambda=382$ (untreated slurry) and $\lambda=383$ (treated slurry), while the corresponding absorbance values were 2.244 for the untreated slurry, 2.695 for the first tank, 3.060 for the second tank, 4.000 for the fourth tank, and 3.079 for the sixth tank. Single peaks were detected in absorption spectras where the observed absorption maximum located. The rest of the spectrums were nearly featureless, showing decreasing absorbance with increasing wavelength.

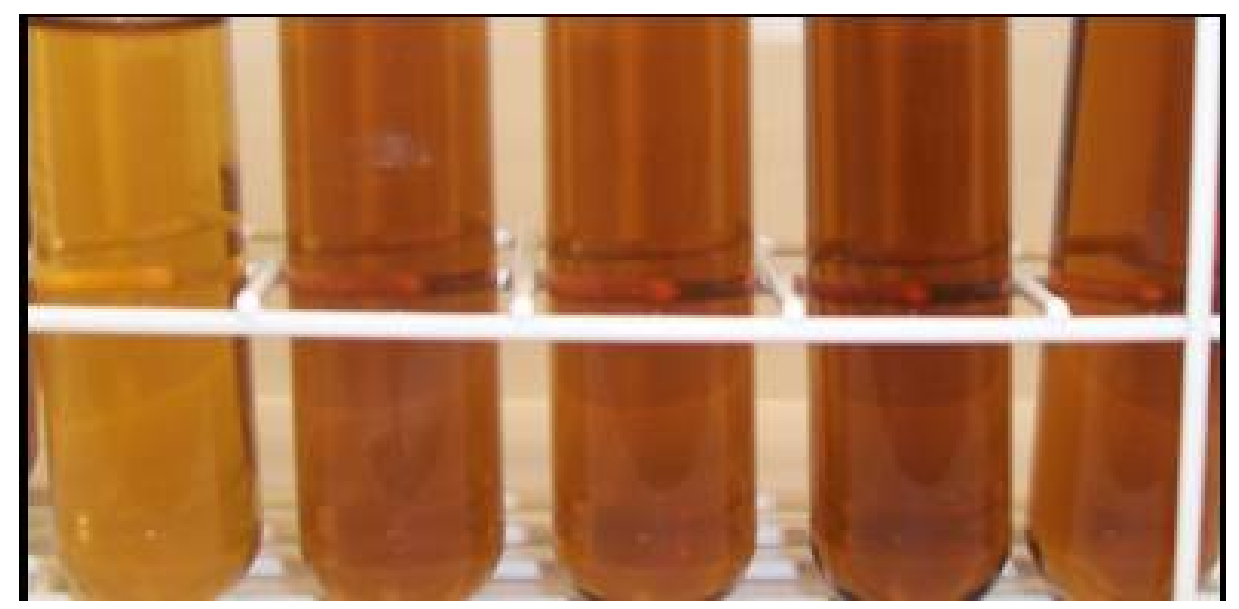

Figure 5. Color intensification during biological treatment process. Microbe-filtered liquid manure samples from left to right: untreated manure, first, second, fourth and sixth tanks of the treatment system. During biological treatment, the color of the liquid manure changes from greyish-green to dark brown

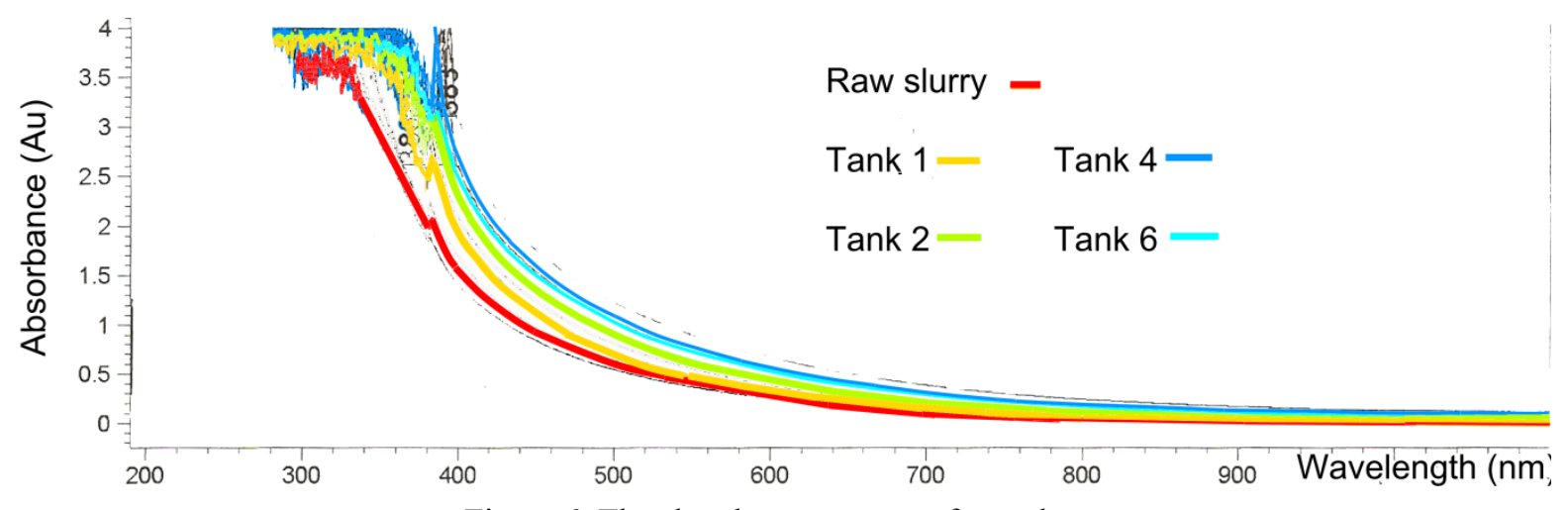

Figure 6. The absorbance spectra of samples

\section{Discussion}

Swine slurry is known to differ considerably in its chemical features from municipal wastewater. However, the applied methods often follow the conventional treatment scheme originally designed for wastewater treatment, or for the chemical industry. 


\subsection{Primary Treatment before Biological Treatment}

Part of the manure solid content was separated prior to aeration treatment simply by sedimentation, which facilitated a $0.53-0.58 \%$ TS content. This TS content is very low and was due to low raw slurry TS content (1.1-1.2\%) before sedimentation step. According to Zhu et al. (2008), in order to reduce aeration time and rates, the manure TS content should not exceed $1 \%$. Although in the present study this was achieved by mere sedimentation, generally the raw slurry TS content is considerably higher, on average $3.5 \%$ (Vilajvuuspalvelu, 2012), in which case to achieve the less than $1 \%$ solids content becomes considerably more challenging.

Slurry properties, such as inherent high buffering capacity and neutral carbohydrates (cellulose, hemicellulose (Chen et al., 2003)), make chemical precipitation difficult. It is often necessary to have high amounts of coagulants; which makes the approach economically unprofitable. Another drawback is that, when iron or aluminium coagulants are used, $\mathrm{P}$ in $\mathrm{Al}$ - or $\mathrm{Fe}$-precipitates are typically unavailable for field crops. Flocculation agents and/or gravity sedimentation are often used to reduce TS content to a level which makes it possible to remove carbon and nitrogen in gaseous form during secondary treatment. Suzuki (2010) reported an average swine waste water suspended solid (SS) content of $1200 \mathrm{mg} / \mathrm{L}$ obtained with a dewatering device with flocculants or gravity sedimentation as the primary treatment.

\subsection{Aeration Treatment with an Alternative Goal}

An ecologically sound approach would recycle carbon back to the soil, rather than release it into the atmosphere as carbon dioxide. During treatment, from 3.8 to $6.1 \%$ of TS was removed with HRT $=3$ and HRT $=4$, respectively. The respective aeration rates varied from 0.6 to $6.5 \mathrm{mg} / \mathrm{L}$ with $\mathrm{HRT}=3$, and from 1.5 to $7.2 \mathrm{mg} / \mathrm{L}$ with HRT $=4$. Only less than $15 \%$ of the carbon was removed. Comparing the obtained results to other studies is difficult, because the presented system includes a series of six continuously fed aerated tank reactors operated with feedback, while in other systems usually one reaction tank is used. Also the intensity of aeration varies from study to study and affects the decomposition of solids. Zhang et al. (2004) reported 1.6-11.1\% of TS removal during five days aeration when initial slurry TS level was $0.5-4.0 \%$ under $35 \mathrm{mV}$ oxidation-reduction potential in single reactor system while TS removal percentages varied from $8.4 \%$ to $30.5 \%$ with increasing aeration to 3.0 $\mathrm{mg} / \mathrm{L} \mathrm{O}_{2}$. Suzuki (2010) reported average effluent concentrations of both SS and BOD $58 \mathrm{mg} / \mathrm{L}$ in activated sludge treatment of swine wastewater (over 95\% reduction in SS concentration during activated sludge processing). Only a highly efficient primary treatment prior to strong aeration would allow these values to be achieved with manure slurry. The price would be the binding of phosphorus in a form that is unusable for plants, losing part of the carbon as carbon dioxide to the atmosphere and changing nitrogen into nitrate, often further denitrified to $\mathrm{N}_{2}$.

\subsection{Enhancing Precipitation by Aeration in Suspended Rich Solution}

The colour of the liquid manure, as well as the liquid's tendency towards flocculation (divalent cations precipitation) changed due to processing. The observed dark colour refers to browning reaction and, consequently, the formation of humus-like compounds (complex dark-coloured polymers, derived from the breakdown of biological residues and from biological metabolites, which undergo polymerisation and/or polycondensation (Stevenson, 1982), which has also been reported by others, such as Juteau et al. (2004). They reported that at higher temperatures the intensity of the effluent color increased and simultaneously decomposition of organic material declined during biological swine manure treatment. In the present study the color was intensified during processing from one tank to the next. The obtained spectrum profiles in the visible region $(400-800 \mathrm{~nm})$ had a pattern similar to that observed by Juteau et al. (2004) that is a nearly featureless absorption spectrum showing decreasing absorbance with increasing wavelength. This pattern is consistent with the absorption spectrum of humus compounds (Stevenson, 1982).

Complex recondensation of simple biochemicals formed during biological waste water treatment has also been reported (e.g. Dignac et al., 2000). Dignac et al. (2000) suggested that intense biological activity could enhance recondensation processes in the aeration basins. Compared to waste water, swine slurry contains higher amounts of soluble organic compounds, which probably further increases the recondensation processes during biological treatment in suspended media. The formed refractory organic matter is undesired in traditional waste water treatment, but could be beneficial in slurry treatment. Humus forming reactions would serve as natural coagulants, facilitating precipitation of hardly precipitating compounds and reducing the amount of precipitating chemicals need. The divalent cations, such as $\mathrm{Ca}^{2+}$ and $\mathrm{Mg}^{2+}$, easily form stable complex ions by chelation, which forms relatively insoluble precipitation products (Stevenson, 1982). This can be one reason for the decline in the concentration of divalent cations, which continued throughout the treatment. 
The low initial concentration of phosphate phosphorus probably caused the negligible phosphate reduction during processing, despite a high $\mathrm{pH}$. According to Zhu et al. (2001) an increase in $\mathrm{pH}$ to 8 can reduce soluble $\mathrm{P}$ concentration by $80 \%$. The fact that Ptot was $31-49 \%$ lower after treatment may be due to enhanced flocculation during treatment and sedimentation at the bottom of the treatment tanks. Juteau et al. (2004) reported 9-19\% Ptot reduction and, even without a settling period, sediment build up was observed.

\section{$5.4 \mathrm{pH}$}

Biological aeration treatment raised the slurry $\mathrm{pH}$ to a $\mathrm{pH}$ value of 8.7. Such a $\mathrm{pH}$ raise is a well-known effect of manure slurry aeration and has been reported by several authors, such as Zhu et al. (2001) and Stevens \& Cornforth (1974). A complex chemical buffering system controls manure $\mathrm{pH}$ change. The most important buffer components are total ammoniacal nitrogen, total inorganic carbon $\left(\mathrm{CO}_{2}, \mathrm{HCO}_{3}{ }^{-}, \mathrm{CO}_{3}{ }^{2-}\right)$, VFAs and other organic compounds (e.g. Sommer \& Husted, 1995). Previously described reasons for $\mathrm{pH}$ changes during aerobic biological treatment can be found in Alitalo et al. (2012).

Part of the $\mathrm{pH}$ increase during aerobic biological treatment coincides with an increased $\mathrm{CO}_{2}$ release from the system in relation to $\mathrm{NH}_{3}$ as also described by Alitalo et al. (2012) and is attributable to the solubility difference between these two components. In the present study slurry $\mathrm{NH}_{4}{ }^{+} / \mathrm{DIC}$ was larger for the treated compared to untreated manure (the respective $\mathrm{NH}_{4}^{+} / \mathrm{DIC}$ - value for the treated (1.01, with $\mathrm{HRT}=4 ; 1.00$ with $\mathrm{HRT}=3$ ) compared to the untreated $(0.85$ with $\mathrm{HRT}=4 ; 0.90$ with $\mathrm{HRT}=3)$ manure $)$.

\subsection{Nitrogen}

Aeration may cause nitrogen loss by (1) volatilization of ammonia (at $\mathrm{pH} 8.8$, already $20 \%$ of total ammoniacal nitrogen will be in $\mathrm{NH}_{3}$ molecules at $20^{\circ} \mathrm{C}$ (Alitalo et al., 2012) and (2) trough biological processes if the oxygen concentration is appropriately adjusted. The most common biological processes include nitrification, which oxidizes ammonium via nitrite to nitrate by autotrophs under aerobic conditions, and denitrification, which transforms nitrate into nitrite, then into nitrous oxide, nitric oxide, and finally to $\mathrm{N}_{2}$ gas by denitrifying bacteria under anaerobic conditions (Wiesmann,1994).

In the present study, the influence of high $\mathrm{pH}$ on $\mathrm{Ntot}$ or $\mathrm{NH}_{4}{ }^{+}-\mathrm{N}$ concentrations was less marked. Neither Ntot nor $\mathrm{NH}_{4}{ }^{+}-\mathrm{N}$ concentration reduced significantly during the treatment. Therefore, it is probable that no marked ammonia emissions took place, which was unexpected since high $\mathrm{pH}$ in reactor tanks. Ammonium nitrogen was not nitrified to nitrate either in the process. It is likely that the high ammonium concentration, together with high $\mathrm{pH}$ and high organic carbon concentration in the treatment chambers, inhibited nitrate formation. According to $\mathrm{Li}$ and Zhao (1999), the initial $\mathrm{NH}_{4}{ }^{+} \mathrm{N}$ concentration should be limited below $100 \mathrm{mg} / \mathrm{L}$ in order to avoid any significant inhibition of microbial activity. High-strength ammonia nitrogen inhibits the activity of bacteria, including organics-utilizing bacteria and nitrifying bacteria, and it is well known that high ammonia concentrations cannot be remediated easily by conventional biological treatments. However, if the treatment principle is to preserve carbon and nitrogen in a system, like in the present study, this (inhibiting effect) is rather an advantage.

\subsection{Odor}

Of all the studies parameters studied, manure processing probably reduced odor the most. Of the studied HRTs, the best odor reduction was achieved with the HRT of the total system being four days. The odor level decreased to faint when the HRT was three days.

Compared to the achieved odor reduction, the VFA reduction was surprisingly small, only $3.1-13.8 \%$ during processing. Zhang et al. (2004) reported an over $90 \%$ reduction of VFAs during five days' aeration treatment with TS content $0.5-1.0 \%$ (aeration intensities $1-3 \mathrm{mg} \mathrm{O} / \mathrm{L}$ ). One explanation could be the low initial VFA concentration in the present study. The other explanation can be in the formation of humus-like compounds. According to the method of esterification (Hach, 1993), the VFAs measurement is based on esterification of the carboxylic acids present in the sample followed by colorimetric determination of the esters produced by the ferric hydroxamate reaction. Therefore, it measures all the compounds containing carboxylic groups, which may have formed. On the other hand, fatty acids represent only a part of odor forming compounds. More than 300 odorous compounds have been identified in swine manure (Hagenstein, 2003).

The odor reduction in aerated systems is frequently explained by oxidation of biodegradable organic material into stable inorganic end products by aerobic bacteria (e.g. Westerman \& Zhang, 1997). This study suggests the formation of humus-like compounds with simultaneous marked odor reduction in the absence of extensive aeration. It may be that the odor compounds are involved in the condensation reactions forming humic 
compounds. That is, instead of complete oxidation, a part of the odor compounds are forming stable humus-like compounds. This could be one explanation for the effective odor decrease in this present system.

\subsection{Benefits of Serial Reactors System}

Bioprocesses are frequently vulnerable to malfunctions posed by changes to the quantity or quality in the supply; for example, inhibition of the production of biogas during anaerobic digestion caused by antibiotics (Sanz et al., 1996). A serial system of small reactors is less susceptible to malfunctions than a larger reactor with a volume that equals the total volume of the serial system. The serial configuration prevents interferences from spreading throughout the entire system, because supply to a tank comes solely from the previous tank; for example, tank 3 receives only the effluent from tank 2 , and so on. Also, the volume of the flow in a given time from one treatment tank to the next is very small in relation to the total volume of the treatment tank and the total volume of the entire system. Thus, the serial configuration and the feedback both function as a buffer mechanism against process interferences and strengthen the process stability. In addition, it is possible that different functional operations take place in different process tanks, which intensifies the treatment process e.g. odor reduction. Benefits of a serial system have been identified in biogas production, for example (Kanokwan \& Angeliadagi, 2009). However, due to the aeration demand of the treatment tanks, it is necessary to assess whether a six-tank system is necessary, or whether, for example a four process tank system would be adequate to achieve the desired result.

\section{Conclusions}

A series of continuously fed aerated tank reactors system was conducted to treat swine slurry to test how moderate or only slight aeration influences slurry properties, and to determine is odor reduction possible in the absence of extensive aeration simultaneously preserving carbon and nitrogen in effluent. The introduced treatment system reduced odors efficiently. No odor or only very faint odor remained after only four days of processing. Total organic carbon reduction during processing remained under $15 \%$. Treatment also facilitated slurry precipitating/coagulation characteristics, which was observed as a color change and a decline in the concentration of divalent cations and total phosphorus. The $\mathrm{pH}$-value at the end of the treatment rose above $\mathrm{pH}$ 8.5 , but there was no significant reduction in Ntot and $\mathrm{NH}_{4}{ }^{+}-\mathrm{N}$ concentrations. This treatment is designed to be part of a total treatment system in which part of the $\mathrm{P}$ is first separated. After this this described biological treatment and biological $\mathrm{pH}$ raise, $\mathrm{N}$ is separated with air stripping. Thereafter chemical treatment with coagulants and water separation follows. The presented total treatment scheme enables nutrient recovery and preservation in a concentrated form, which can be used as fertilizers, and recycling of carbon back to soil. Arisen subjects of more detailed future work include the connection between odor reduction and formation of humic-type compounds and fate of inoculant in a treatment system. Thus, our results provide a starting point, rather than the final world.

\section{Acknowledgements}

This project was partly supported by the Ministry of Agriculture and Forestry of Finland and Teknillis-Yhteiskunnallinen Tutkimussäätiö. The first author was supported by the Academy of Finland under contract No. 130803. The authors wish to give special thanks to technicians Risto Seppälä and Katariina Saarela for their assistance with the experimental work.

\section{References}

Alitalo, A., Kyrö, A., \& Aura, E. (2012). Ammonia stripping of biologically treated liquid manure. Journal of Environmental Quality, 41, 273-280. http://dx.doi.org/10.2134/jeq2011.0286

Burton, C. H. (1992). A review of the strategies in the aerobic treatment of pig slurry: purpose, theory and method. Journal of Agricultural Engineering Research, 53, 249-272. http://dx.doi.org/10.1016/0021-8634(92)80086-8

Chen, S., Liao, W., Liu, C., Wen, Z., Kincaid, R. L., Harrison, J. H., ... Stevens, D. J. (2003). Value-Added Chemicals from Animal Manure. PNNL-14495, Pacific Northwest National Laboratory, Richland, WA. http://dx.doi.org/10.2172/15009485

Dignac, M.-F., Ginestet, P., Rybacki, D., Bruchet, A., Urbain, V., \& Scribe, P. (2000). Fate of wastewater organic pollution during activated sludge treatment: nature of residual organic matter. Water Research, 34, 4185-4194. http://dx.doi.org/10.1016/S0043-1354(00)00195-0

Grubbs, R. B. (1979). Bacteria supplementation: what it can and can't do. 9th Eng. Foundation Conference in Environmental Engineering in the Food Processing Industry, Pacific Grove, CA. 27 Feb. 1979. ASCE, 
Reston, VA.

Hagenstein, P. (2003). Air Emissions from Animal Feeding Operations: Current Knowledge, Future Needs, Washington (DC): National Academies Press.

Juteau, P., Tremblay, D., Ould-Moulaye, C.-B., Bisaillon J.-G., \& Beaudet, R. (2004). Swine waste treatment by self-heating aerobic thermophilic bioreactors. Water Research, 38, 539-546. http://dx.doi.org/10.1016/j.watres.2003.11.001

Kanokwan, B., \& Angelidaki, I. (2009). Serial CSTR digester configuration for improving biogas production from manure. Water Research, 43, 166-172. http://dx.doi.org/10.1016/j.watres.2008.09.041

Li, X., \& Zhao, Q. (1999). Inhibition of microbial activity of activated sludge by ammonia in leachate. Environment International, 25, 961-968. http://dx.doi.org/10.1016/S0160-4120(99)00068-9

Littell, R. C., Milligan, G. A., Stroup, W. W., \& Wolfinger, R. D. (1996). SAS System for Mixed Models. SAS Institute Inc. Cary NC.

Paduch, M. (1988). Present state of VDI-guidelines on odour assessment. In Volatile emissions from livestock farming and sewage operations (pp. 38-53). New York: Elsevier Applied Science.

Pain, B. F., Thompson, R. B., De La Cremer, L. C. N., \& Ten Holte, L. (1987). The use of additives in livestock slurries to improve their flow properties, conserve nitrogen and reduce odours. In H. G., Van Der Meer, R. J., Unwin, T. A., Van Djik, \& G. C. Ennik. (Eds.), Development in Plant Soil Sciences. Animal manure on grassland and fodder crops. Fertiliser or waste? Martius Nijhoff Publishing., Dordrecht, pp. 229-246. http://dx.doi.org/10.1007/978-94-009-3659-1_14

Powers, W. J. (2004). The science of smell, part 3: odor detection and measurement. Iowa State University Extension PM 1963c.

Ritter, W. F. (1981). Chemical and biochemical odour control of livestock wastes: A review. Canadian Agricultural Engineering, 23, 1-4.

Sanz, J. L., Rodriguez, N., \& Amils, R. (1996). The action of antibiotics on the anaerobic digestion process. Applied Microbiology and Biotechnology, 46, 587-592. http://dx.doi.org/10.1007/s002530050865

Stevens, R. J., \& Cornforth, I. S. (1974). The effect of aeration on the gases produced by slurry during storage. Journal of the Science of Food and Agriculture, 25, 1249-1261. http://dx.doi.org/10.1002/jsfa.2740251009

Stevenson, F. J. (1982). Humus chemistry: Genesis, composition, reactions. New York: John Wiley \& Sons.

Suzuki K., Waki, M., Yasuda, T., Fukumoto, Y., Kuroda, K., Sakai, T., ... Matsuba, K. (2010). Distribution of phosphorus, copper and zinc in activated sludge treatment process of swine wastewater. Bioresource Technology, 101, 9399-9404. http://dx.doi.org/10.1016/j.biortech.2010.07.014

Viljavuuspalvelu (2012). Soil analysis Service, Manure Statistics from the years 2005-2009. In Finnish. Retrieved November 25, 2012, from http://www.viljavuuspalvelu.fi/sites/default/files/sites/default/files/tilastot/Lantatilasto\%202005\%20-\%2020 09.pdf

Westerman, P. W., \& Zhang, R. H. (1997). Aeration of livestock manure slurry and lagoon liquid for odor control: a review. Applied Engineering in Agriculture, 13, 245-249.

Wiesmann, U. (1994). Biological nitrogen removal from wastewater. Advances in Biochemical Engineering, 51, 113-154. http://dx.doi.org/10.1007/BFb0008736

Zhang, Z., Zhu, J., \& Park, K. (2004). Effects of duration and intensity of aeration on solids decompostition in pig slurry for odour control. Biosystems Engineering, 89, 445-456. http://dx.doi.org/10.1016/j.biosystemseng.2004.08.009

Zhu, J. (2000). A review of microbiology in swine manure odor control. Agriculture, Ecosystems \& Environment, 78, 93-106. http://dx.doi.org/10.1016/S0167-8809(99)00116-4

Zhu, J., Bundy, D. S., Li, X., \& Rashid, N. (1997). The hindrance in the development of pit additive products for swine manure odor control - a review. Journal of Environmental Science and Health A, 32, 2429-2448. http://dx.doi.org/10.1080/10934529709376694 